\title{
Detection of Epstein Barr Virus (EBV) Antigen in Oral Squamous Cell Carcinoma (OSCC) by Immunohistochemistry in Patients from KPK Province of Pakistan.
}

1. BDS, M.Phil (Oral Pathology) PG Oral Pathology Peshawar Dental College,

2. MBBS, FCPS (Histopathology)

Professor Pathology

Peshawar Medical College,

3. BDS, MSc (Public Health)

Assistant Professor CHS

Peshawar Medical College

4. BDS

Registrar Prosthodontics Khyber College of Dentistry,

5. BDS, M.Phil (Oral Pathology)

Assistant Professor Oral Pathology Peshawar Dental College,

6. MBBS, FCPS, FRCS, MRCSEd, FICO (Ophthalmology)

Assistant Professor Ophthalmology Hayatabad Medical Complex,

Peshawar, Pakistan.

Correspondence Address:

Dr. Fatima lqbal

Department of Oral Pathology

Peshawar Dental College Warsak

Road,

Peshawar, Pakistan

khanfatima319@gmail.com

Article received on:

23/01/2021

Accepted for publication:

$15 / 04 / 2021$

\begin{abstract}
Sana Ghani ${ }^{1}$, Fozia Rauf ${ }^{2}$, Asif Rehman ${ }^{3}$, Muhammad Irfan ${ }^{4}$, Fatima Iqbal ${ }^{5}$, Yousaf Jamal $^{6}$
\end{abstract}
ABSTRACT... Objective: To determine the frequency of EBVLMP-1 antigen positivity in OSCC and normal oral squamous epithelial tissues (control) by immunohistochemistry $(\mathrm{IHC})$ and to see the effect of age and gender in both the OSCC and control tissues. Study Design: Descriptive, Cross Sectional, Multicenter study. Setting: Pathology/ Peshawar Medical College (PMC), Peshawar Dental College and Sardar Begum Dental College, Peshawar. Period: April 2018 to September 2018. Material \& Methods: Conducted on total 60 samples divided into two groups. Group A: 30 formalin fixed paraffin embedded tissue blocks of OSCC cases and Group B: 30 non neoplastic oral epithelial tissues (control). Both groups A and B slides were stained through immunohistochemistry for EBV LMP-1 monoclonal antigen. Results: 30 cases of OSCC Group A and 30 cases of non-neoplastic oral mucosa Group B were selected for the LMP-1 staining by immunohistochemistry. The mean age of OSCC was 56.5 years $( \pm 14.47$ Standard deviation) with a range of 20-80 years. Male: Female ratio was 1.3:1 .OSCC commonly involved buccal mucosa. $80 \%(n=24 / 30)$ OSCC cases were grade 1, all the cases of OSCC $(100 \%)$ showed epithelial positivity for EBV LMP-1 antigen, whole (29/30) cases of non-neoplastic oral mucosa cases showed positivity and there is no statistically significant difference in both Groups A and B. Conclusion: With the findings of EBV positivity in both the OSCC and all of the control cases; it is concluded that EBV does not play an important role in etiology of OSCC. This suggests that the infection by this ubiquitous virus (EBV) occurs at some point in the life of a person leaving LMP, protein latent in the cells of oral epithelium.

Key words: $\quad$ Epstein Barr Virus (EBV), Latent Membrane Protein-1(LMP-1), Oral Squamous Cell Carcinoma (OSCC).

Article Citation: Ghani S, Rauf F, Rehman A, Irfan M, Iqbal F, Jamal Y. Detection of Epstein Barr Virus (EBV) Antigen in Oral Squamous Cell Carcinoma (OSCC) by Immunohistochemistry in Patients from KPK Province of Pakistan. Professional Med J 2021; 28(12):1829-1836.

https://doi.org/10.29309/TPMJ/2021.28.12.6379

\section{INTRODUCTION}

Malignancies are becoming a major health problem worldwide. ${ }^{1}$ Oral squamous cell Carcinoma (OSCC) is the $6^{\text {th }}$ most common cancer ${ }^{2}$ which has a high annual morbidity and mortality all over the world. It contributes up to $90 \%$ of total head and neck malignancies. ${ }^{3,4}$

OSCC includes $88 \%$ of mouth and lip malignancy. ${ }^{1,4}$ In 2008, 263,900 new cases and 128,000 deaths were reported from oral cancer. ${ }^{5}$ OSCC variably occurs in different regions of the world which depends upon on certain lifestyle risk factors, e.g. tobacco use, betel quid chewing and alcohol consumption. ${ }^{6}$ The occurrence of OSCC is high in Asia specially in India and Pakistan where it is most common in males and 2nd most common in both sexes. ${ }^{7,8}$ According to Shaukat Khanum cancer registry $2016,5,996$ malignancy cases were diagnosed in which 3,127 were female patients and 2,869 were male. $^{9}$

Among different factors cigarette smoking, betel quid chewing and alcohol consumption are the well-known risk factors for OSCC with the synergistic effect between smoking and alcohol consumption. ${ }^{10}$ Beside these well known risk factors biological oncogenic virus might play an important role in OSCC. Human Papilloma Virus is a well-known oncogenic virus that can cause 
OSCC. ${ }^{11}$ The high risk HPV especially HPV type 16 and 18 are related with OSCC. ${ }^{12,13} \mathrm{HPV}$, EBV is also related with OSCC. ${ }^{6}$

Epstein Barr virus belongs to human herpesvirus group and lymphocryptovirus genus and is present in $90 \%$ of population of world. ${ }^{14-17}$

Epstein Barr virus prevalence is very high and every year 200,000 new cases are infected by EBV. $90 \%$ of people are infected by EBV especially in the first two decades of life. Mode of transmission of EBV is through kissing and sexual contact. EBV causes reversible latent infection in B-cells ${ }^{18}$, enters the epithelial cells and multiply there and then they are released in the saliva, after entering saliva attack B-lymphocytes and spread all over the body. Mostly patients infected with EBV presents with no symptoms. ${ }^{17,19}$

Epstein Barr virus is of two types i.e. EBV type 1 and type 2; these types have allelic polymorphism only. For achieving in vitro B-cell transformation, studies showed that type 1 is more potent than type 2. Type $1 \mathrm{EBV}$ is more common worldwide than type 2 which is only found in Africa. ${ }^{20,21}$

Multiple Benign and malignant diseases in head and neck regions are associated with EBV. Diseases caused by EBV can cause infectious mononucleosis, Burkitt's lymphoma, B-cell lymphoma, peripheral T-cell lymphoma, nasopharyngeal carcinoma, gastric carcinoma and oral squamous cell carcinoma. ${ }^{22,23}$

$90 \%$ of adults have EBV antibodies, EBV can cause infection in 2 target cells i.e. oropharyngeal or salivary gland epithelium and B-cell lymphocytes. ${ }^{14,15}$

Multiple studies in literature reported association of EBV with OSCC. ${ }^{24-27}$ However many studies showed no significant relation of EBV with OSCC. $6,28,29$

Keeping in view these controversial results in literature as well as there is no study conducted in our population to correlate EBV with OSCC, so this study was designed to compare EBV LMP-1 positivity in OSCC and normal controls on IHC.

\section{MATERIAL \& METHODS}

Descriptive, cross- sectional, multicenter study conducted at the Department of Pathology/ Peshawar Medical College (PMC), Peshawar Dental College and Sardar Begum Dental College, Peshawar, during April - September 2018. This study was approved by ethical committee (Prime/ IRB/2020-257).

The study consisted of Group A: Thirty formalin fixed paraffin embedded tissue blocks of OSCC cases and Group B: Thirty non neoplastic oral epithelial tissues (control) removed during operculectomy and gingivectomy procedure. The formalin fixed paraffin embedded blocks of OSCC cases were obtained from different laboratories after permission from lab in charges. The nonneoplastic oral mucosa tissues were collected from different clinics after informed consent from the patients. These tissues were preserved in 10\% buffered formalin, and processed at Peshawar Medical College Histopathology labs.

Formalin fixed paraffin embedded blocks of both group A and B were stained with hematoxylin and eosin stain. The OSCC cases were graded into grade I, II, III according to Broder's grading system. Both groups A and B slides were stained through immunohistochemistry for EBV LMP-1 monoclonal antigen using standard procedures as described in the manual. The intensity of EBV expression was graded as negative (0$5 \%$ epithelial cells) exhibiting cytoplasmic or nuclear brown staining, mild positive (6\%-33\% epithelial cells), moderate positive (34\%-66\% cells) and marked positivity (67\%-100\% cells). The slides were reviewed separately by two histopathologists.

The data was then statistically analyzed by statistical package for the social sciences (SPSS) version 19. The statistical difference between the groups (categorical variables) was calculated by using chi square test and fisher exact test. Statistical significance was determined at $p$ values 0.05 . 


\section{RESULTS}

The study was conducted on 30 diagnosed OSCC cases and 30 non neoplastic oral mucosa cases. The gender distribution of OSCC cases was 17 male patients (56\%) and 13 females (43.3\%). Male to female ratio was 1.3:1. In grade 1 tumor there were 13 female and 10 male patients and for grade 2 there were 3 female and 3 male patients (Table-I).

\begin{tabular}{|l|c|c|c|}
\hline & $\begin{array}{c}\text { Grade 1 } \\
\text { OSCC (n) }\end{array}$ & $\begin{array}{c}\text { Grade 2 } \\
\text { OSCC (n) }\end{array}$ & Total (n) \\
\hline $\begin{array}{l}\text { Mean Age } \\
\text { (years) }\end{array}$ & 55.29 & 61.33 & \\
\hline Gender & \multicolumn{3}{|l|}{} \\
\hline Male & 14 & 3 & 17 \\
\hline Female & 10 & 3 & 13 \\
\hline Total & 24 & 6 & 30 \\
\hline
\end{tabular}

Table-I. Demographics of our study participants.
Of the 30 specimens of OSCC, 24 were incisional biopsies, 5 punch biopsies and 1 excisional biopsy. The age range of OSCC patients was 2080 years. Mean age of OSCC cases was $56.5 \mathrm{yrs}$ (standard deviation \pm 14.27 ) among the 30 OSCC cases, a great majority were those older than 40 years. The distribution of OSCC in the various age groups is given in (Table-II).

When age was correlated with gender, majority of females with OSCC were in $4^{\text {th }}$ decade, while majority of male OSCC cases were in $5^{\text {th }}$ decade. Grade 1 tumors were most frequently seen in 4150 years age group while Grade 2 tumors were seen more frequently in 51-70 years age group (Table-III).

\begin{tabular}{|c|c|c|c|c|c|c|c|c|c|}
\hline & \multicolumn{6}{|c|}{ Age Group } & \multirow{2}{*}{ Total } \\
\hline & & & $20-30$ & $31-40$ & $41-50$ & $51-60$ & $61-70$ & $71-80$ & \\
\hline \multirow{4}{*}{ Disease } & \multirow[b]{2}{*}{ OSCC } & Count & 1 & 2 & 8 & 7 & 6 & 6 & 30 \\
\hline & & $\begin{array}{l}\% \text { within } \\
\text { Age Group }\end{array}$ & $3.3 \%$ & $6.7 \%$ & $26.7 \%$ & $23.3 \%$ & $20 \%$ & $20 \%$ & $100 \%$ \\
\hline & \multirow[b]{2}{*}{ Control } & Count & 5 & 2 & 6 & 7 & 5 & 5 & 30 \\
\hline & & $\begin{array}{l}\% \text { within } \\
\text { Age Group }\end{array}$ & $16.6 \%$ & $6.6 \%$ & $20 \%$ & $23.3 \%$ & $16.6 \%$ & $16.6 \%$ & $100 \%$ \\
\hline
\end{tabular}

Table-II. Age-wise Distribution of OSCC Cases.

\begin{tabular}{|l|c|c|c|}
\hline $\begin{array}{c}\text { Age Groups } \\
\text { Years }\end{array}$ & Grade 1 & Grade 2 & P-Value \\
\hline$<50$ & $11(36 \%)$ & $1(3.3 \%)$ & \\
\hline $51-60$ & $4(13.3 \%)$ & $2(6.6 \%)$ & \\
\hline $61-70$ & $4(13.3 \%)$ & $2(6.6 \%)$ & 0.49 \\
\hline $71-80$ & $5(16.6 \%)$ & $1(3.3 \%)$ & \\
\hline Total & 24 & 6 & \\
\hline \multicolumn{3}{|c|}{ Table-III. Association of OSCC Grades with age } \\
groups.
\end{tabular}

To determine the intensity of EBV expression in epithelial cells of OSCC cases and normal epithelium controls; 4 categories were defined base on the number of epithelial cells showing nuclear or cytoplasmic brown staining with EBV LMP-1 antigen on immunohistochemistry (TableIV). All cases of OSCC demonstrated positivity for LMP-1 protein on IHC, However intensity of staining was different in different cases. Most of the OSCC cases i.e. 18/30 showed moderate positivity for EBV LMP-1(60\%), followed by marked positivity in 8 cases (26.7\%) and mild positivity in 4 cases (13.3\%). When the epithelial expression of EBV LMP-1 antigen in OSCC and control groups was compared by fisher exact test, there was no statistically significant difference in epithelial expression of two groups, the p-value was 0.45 .

\begin{tabular}{|c|c|c|c|}
\hline $\begin{array}{l}\text { \% Age of epithelial } \\
\text { cells positive for EBV }\end{array}$ & oscc & Controls & $\begin{array}{c}\text { P- } \\
\text { Value }\end{array}$ \\
\hline $0-5 \%$ & 0 & $1(3.3 \%)$ & \multirow{5}{*}{0.45} \\
\hline Mild (5\%-33\%) & $4(13.3 \%)$ & $4(13.3 \%)$ & \\
\hline Moderate (33\%-66\%) & $18(60 \%)$ & $13(43.3 \%)$ & \\
\hline Marked (66\%-99\%) & $8(26.7)$ & $12(40 \%)$ & \\
\hline Total & $30(100 \%)$ & $30(100 \%)$ & \\
\hline
\end{tabular}


Figure-1 shows that the Buccal mucosa was the commonest site involved by OSCC in 15 cases $(50 \%)$ followed by alveolar mucosa in 9 cases $(30 \%)$, tongue in 2 cases $(6.7 \%)$, buccal vestibule in 2 cases (6.7\%), lip in 1 case (3.3\%), and anterior maxillary mucosa in 1 case (3.3\%). Commonest site involved in male patients was buccal mucosa in 8 out of 15 and for female patients the commonest site was also the same in 7 out of 15 cases. The Grade I tumors were commonly located in buccal mucosa in 12 out of $24(50 \%)$ followed by alveolar mucosa in 8 out of 24 , anterior maxillary mucosa in 1 out of 24 , lip in 1 out of 24, while location in oral cavity for Grade II tumors was buccal mucosa in 3 out of 6 , followed by buccal vestibule in 2 out of 6 , alveolar mucosa in 1 out of 6 .

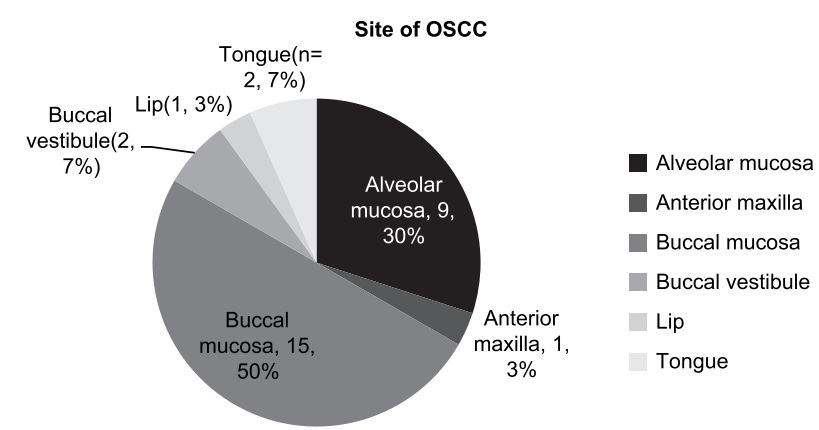

Figure-1: Location of lesion in oral cavity.

Gingival mucosa (80\%) was the commonest site in healthy controls followed by alveolar mucosa (20\%).Majority of cases normal oral mucosa i.e. control group also exhibited moderate EBV positivity in 13 cases (43\%) followed by marked positivity in 12 cases (40\%) and mild EBV positivity in 4 cases $(13.3 \%)$.

Table 5 shows that when the epithelial expression of EBV LMP-1 immunohistochemical expression was compared among the different age groups of OSCC cases and control case there was no statistical difference between the two groups. A statistically non-significant $p$ value of 0.47 was obtained by chi square test. There was no statistical difference in male and female cases regarding EBV LMP-1 antigen positivity.

\begin{tabular}{|c|c|c|c|}
\hline \multirow{2}{*}{$\begin{array}{l}\text { Age Groups } \\
\text { Years }\end{array}$} & \multicolumn{2}{|c|}{ Epstein Barr Virus } & \multirow[t]{2}{*}{ P-Value } \\
\hline & Yes & No & \\
\hline $20-30$ & 6 & 0 & \multirow{7}{*}{0.476} \\
\hline $31-40$ & 4 & 0 & \\
\hline $41-50$ & 14 & 0 & \\
\hline $51-60$ & 14 & 0 & \\
\hline $61-70$ & 10 & 1 & \\
\hline $71-80$ & 11 & 0 & \\
\hline TOTAL & 59 & 1 & \\
\hline
\end{tabular}

Majority of OSCC grade 1 cases showed moderate epithelium positivity $(n=13 / 24)$, marked $(n=7 / 24)$ and 4 cases of grade 1 OSCC showed mild nuclear staining. Regarding Percentage of EBV positive cells in epithelium, in GRADE II-OSCC cases, majority of cases $(n=5)$ showed moderate nuclear positivity of EBV in 33-66\% of epithelial cells, and one case showed marked positivity i.e. $66-99 \%$ epithelial cells. The epithelial expression intensity of EBV LMP-1 in Grade I OSCC cases was compared to that of Grade II cases. The $p$ value came out to be 0.53 which showed no statistically significant difference in EBV LMP-1 expression intensity between the two grades of OSCC. (Table-VI)

\begin{tabular}{|c|c|c|}
\hline $\begin{array}{l}\text { Grade of } \\
\text { OSCC }\end{array}$ & $\begin{array}{l}\text { \%age of Epithelial Cells } \\
\text { Positive for EBV-LMP1 }\end{array}$ & P-Value \\
\hline \multirow{3}{*}{$\begin{array}{l}\text { Grade } 1 \\
(n=24)\end{array}$} & $1=4$ & \multirow{6}{*}{0.53} \\
\hline & $2=13$ & \\
\hline & $3=7$ & \\
\hline \multirow{3}{*}{$\begin{array}{l}\text { Grade } 2 \\
(n=6)\end{array}$} & $1=0$ & \\
\hline & $2=5$ & \\
\hline & $3=1$ & \\
\hline \multicolumn{3}{|c|}{$\begin{array}{l}\text { Table-VI. EBV (LMP-1) Expression in relation with } \\
\text { different grades of OSCC Cases. }\end{array}$} \\
\hline
\end{tabular}

\section{DISCUSSION}

Multiple studies have been conducted to find an association of Epstein Barr Virus in OSCC employing different laboratory detection techniques e.g. immunohistochemistry and PCR. ${ }^{29,30}$ In our study there were $90 \%$ cases of OSCC with ages more than 40 years, confirming that OSCC is age related. Two studies found that 
OSCC is more frequent in older age. ${ }^{8,31}$ In our study $26.7 \%$ of OSCC were in the age group of 41 50 years which is similar to the study conducted at Ayub Medical college in which more cases were in the age group of 41-50 years. ${ }^{32}$ In our study the youngest of all patients affected was 20 years and the oldest was 80 years which is similar to the study from India. ${ }^{7}$ The mean age in our study is 56.5 with a standard deviation of \pm 14.2 , similar to studies from Lahore with the mean age (50.3years) and from Iran with the mean age (58.6years) and India with mean age (58.2years). ${ }^{31,33,34}$

There was not much difference in male and female ratio of OSCC cases in our study male $56 \%$ and female $44 \%$ which is similar to the study by Zulfiqar et al 2013 (male 53\% and female 46\%). Contrary to our results Sheikh at al 2014 from Karachi and Shujata et al 2017 report OSCC to be more frequent in male patients $62 \%$ and $60 \%$ respectively. Shenoi et al 2012 from India quite reported a very high frequency of OSCC in males (81\%). In addition some studies have shown higher tendency to acquire OSCC in female population e.g study by Saravani et al 2014 from Iran has (69\%) female and (31\%) male OSCC patients. . $^{7,8,31,33,34}$

In our study commonest site for OSCC was buccal mucosa (50\%), followed by alveolar mucosa (30\%). This is in accordance with studies where the commonest location was found to be buccal mucosa in 45\%, 32\%, and 34\% OSCC cases respectively. $8,31,32$

However studies from UHS Lahore, reported tongue to be the commonest site (23\% cases) and Spain reported lower lip (76\% cases) to be the commonest site, these varied locations may be because of different personal habits and exposure to different environmental carcinogens in different geographic areas. ${ }^{33,35}$

While correlating grade of OSCC with site, the commonest site encountered in both grade I and grade II cases was buccal mucosa (50\%).

In our study majority of cases were in grade 1
(80\%) followed by grade 2 (20\%) while grade 3 cases were not encountered (Table-II). These results are similar to the study from Iran $^{31}$ where majority of cases were in grade 1 (43.75\%) followed by grade 2 (39.5\%). While our results are in contrast to one of the study ${ }^{33}$ where majority of cases were in grade 2 (51\%) followed by grade 1 (25\%) and Shujata et al 2017 68\% cases were in grade II. In our study there was no significant correlation between age groups and grades of OSCC ( $p$ value 0.49 ) which is in accordance with study. ${ }^{31,34}$

When the staining intensity of EBV in OSCC cases and controls group was compared, the $p$ value was not statistically significant. The prevalence of EBV infection in OSCC has been reported from $0 \%-100 \%$ in different studies from different areas of the world Reddy, 2017 (8\%), Saravani, 2014 (16.7\%), Acharya, 2015 (45.05\%), Kis, 2009 (73.8\%), Shamaa, 2008 (81.8\%), Cruz, 2000 (100\%). Studies from Taiwan and Japan have given highest frequency of EBV positivity similar to our results even with PCR and chip hybridization (82.5\%). ${ }^{6,24,26,28,30,31,34}$

Our results were comparable with Sujatha et al 2017 from India where the study compared 3 groups, OSCC, OPMD, and normal controls on IHC for EBV LMP-1 antigen. All the 3 groups had similar expression of EBV with no statistical significance. ${ }^{34}$

Our results were also comparable to two studies by I Cruz et al, first study in1997, 100\% of OSCC cases were positive for EBV DNA using PCR on frozen blocks. There was no statistical significance when the EBV status was correlated with gender, age, location, histological grade. ${ }^{36}$

In a follow up study by I Cruz in 2000, employing several different techniques (e.g. ISH, RT-PCR and IHC ) on 9 samples selected out of previously EBV positive cases in 1997 study, showed that all of them had no active transcripts and the EBV positivity in has no causal relationship with OSCC. ${ }^{24}$

However in contrast to our study, there are studies 
reporting statistically significant association between EBV and OSCC e.g. Sand et al 2002 from Sweden detected EBV DNA by PCR in tumor tissue of $11 / 29$ (37.9\%) OSCC cases as compared to control group (7.3\%) and the results were statistically significant. ${ }^{37}$

Shamaa A et al from Egypt studied LMP-1 and topoisomerase on paraffin embedded tissue $(18 / 22)$ OSCC (81.8\%) were positive for anti EBV antibody however the controls were (62.5\%). ${ }^{28}$

Acharya et al 2014 in a study at North East Thailand on exfoliated normal mucosa cells 41/91 (45.05\%) were positive for EBV DNA by PCR and $26 / 80$ (32.5\%), OSCC cases showed that oral cytology was positive for EBV infection their results were statistically significant as only $19 \%$ of controls showed positivity for EBV. They suggest EBV to be an etiological risk factor. ${ }^{6}$

Kikuchi et al Japan studied 30 normal mucosa, 150 OSCC cases for LMP-1 and EBNA-2, by PCR, $\mathrm{ISH}$ and $\mathrm{IHC}$ methods more cases of severe dysplasia showed positivity for LMP-1 (44.4\%) as compared to OSCC (10.7\%) or normal mucosa (23.3\%). This higher expression level of EBV in severe epithelial dysplasia as compared to SCC was hypothesized to play an important role in dysplasia-carcinoma sequence in the oral cavity. The widespread expression of EBV in control group and OSCC cases of our study suggested lack of any causal relationship between the EBV infection and OSCC pathogenesis and the infection may just be latent in the oral cells that later on underwent malignant transformation, or the malignant cells may have got an infection at later stage. ${ }^{38}$

Age groups of OSCC and control case with EBV LMP-1 expression, all cases in OSCC group were positive for EBV LMP-1, while in control group only 1 case was negative and the rest of all are positive, our results were similar to Saravani et al 2014 from Iran where there was no correlation found between viral load of EBV positive cases and patients age. ${ }^{31}$

Comparing gender with EBV LMP-1 positivity, in OSCC cases all male and female were positive while in non-neoplastic controls only 1 male was negative and all female cases were positive, $P$ value of 0.53 shows that the result is not statistically significant, suggesting that infection of EBV is not gender related similar to Saravani et al 2014 and I Cruz et al where no statistical association was observed between EBV viral load and gender. ${ }^{24,31}$

When different Grades were statistically correlated for Epithelial EBV LMP-1 positivity our results were not statistically significant, similar to study by (Saravani et al., 2014) where no correlation was demonstrated between viral load of EBV by PCR analysis and the grades of OSCC. ${ }^{31}$

\section{CONCLUSION}

Epstein Barr Virus infection by immunohistochemical expression of latent membrane protein antigen was same in both OSCC cases and non-neoplastic oral mucosa tissue, without any significant statistical difference between the two groups, which suggests that causal relationship between EBV and OSCC is less likely.

EBV LMP-1 antigen was found positive in all age groups, and both genders with no special predilection towards any age group or gender.

Copyright(C) 15 Apr, 2021.

\section{REFERENCES}

1. Khan MA, Saleem S, Shahid SM, Hameed A, Qureshi NR, Abbasi Z, et al. Prevalence of oral squamous cell carcinoma (OSCC) in relation to different chewing habits in Karachi, Pakistan. Pak J Biochem Mol Biol. 2012; 45(2):59-63.

2. Metgud R, Astekar M, Verma M, Sharma A. Role of viruses in oral squamous cell carcinoma. Oncology reviews. 2012; 6(2).

3. Bray F, Ferlay J, Soerjomataram I, Siegel RL, Torre LA, Jemal A. Global cancer statistics 2018: GLOBOCAN estimates of incidence and mortality worldwide for 36 cancers in 185 countries. CA: a cancer journal for clinicians. 2018; 68(6):394-424.

4. El-Naggar AK. WHO classification of head and neck tumours: International Agency for Research on Cancer; 2017. 
5. Jemal A, Bray F, Center MM, Ferlay J, Ward E, Forman D. Global cancer statistics. CA: a cancer journal for clinicians. 2011; $61(2): 69-90$.

6. Acharya S, Ekalaksananan T, Vatanasapt P, Loyha $\mathrm{K}$, Phusingha $\mathrm{P}$, Promthet $\mathrm{S}$, et al. Association of Epstein $\square$ Barr virus infection with oral squamous cell carcinoma in a case-control study. Journal of Oral Pathology \& Medicine. 2015; 44(4):252-7.

7. Shenoi R, Devrukhkar V, Sharma B, Sapre S, Chikhale A. Demographic and clinical profile of oral squamous cell carcinoma patients: A retrospective study. Indian journal of cancer. 2012; 49(1):21.

8. Shaikh AH, Mohammad T, Qureshi NR. Histopathological patterns of oral squamous cell carcinoma. Pakistan Oral \& Dental Journal. 2014; 34(3).

9. Mahmood S, Faraz R, Yousaf A. Annual cancer registry report-2016, of the Shaukat Khanum Memorial Cancer Hospital \& Research Center. PAKISTAN; 2016.

10. Hashibe M, Brennan P, Chuang S-C, Boccia S, Castellsague $\mathrm{X}$, Chen $\mathrm{C}$, et al. Interaction between tobacco and alcohol use and the risk of head and neck cancer: Pooled analysis in the International Head and Neck Cancer Epidemiology Consortium. Cancer Epidemiology and Prevention Biomarkers. 2009; 18(2):541-50.

11. Agrawal GP, Joshi PS, Agrawal A. Role of HPV-16 in pathogenesis of oral epithelial dysplasia and oral squamous cell carcinoma and correlation of p16ink4a expression in HPV-16 positive cases: An immunohistochemical study. ISRN Pathology. 2013;2013.

12. Sugiyama M, Bhawal UK, Dohmen T, Ono S, Miyauchi $M$, Ishikawa T. Detection of human papillomavirus-16 and HPV-18 DNA in normal, dysplastic, and malignant oral epithelium. Oral surgery, oral medicine, oral pathology, oral radiology, and endodontology. 2003; 95(5):594-600.

13. Zhang Z-Y, Sdek $P$, Cao J, Chen W-T. Human papillomavirus type 16 and 18 DNA in oral squamous cell carcinoma and normal mucosa. International journal of oral and maxillofacial surgery. 2004; 33(1):714.

14. Jiang $\mathrm{R}, \mathrm{Gu} X$, Moore-Medlin TN, Nathan C-A, Hutt-Fletcher LM. Oral dysplasia and squamous cell carcinoma: correlation between increased expression of CD21, Epstein-Barr virus and CK19. Oral oncology. 2012; 48(9):836-41.
15. Santos L, Azevedo K, Silva L, Oliveira L. Epstein-Barr virus in oral mucosa from human immunodeficiency virus positive patients. Revista da Associação Médica Brasileira. 2014; 60(3):262-9.

16. Patil S. Etiologic Association between EpsteinBarr Virus and Oral Squamous Cell Carcinoma: A Brief Evidence-based Discussion. The journal of contemporary dental practice. 2017; 18(4):261-4.

17. Al-Kobaisi MF. Jawetz, Melnick \& Adelberg's Medical Microbiology 24th Edition. Sultan Qaboos University Medical Journal [SQUMJ]. 2007; 7(3):273-5.

18. Ueda S, Uchiyama S, Azzi T, Gysin C, Berger C, Bernasconi $M$, et al. Oropharyngeal group $A$ streptococcal colonization disrupts latent EpsteinBarr virus infection. The Journal of infectious diseases. 2013; 209(2):255-64.

19. de França TRT, Carvalho AdAT, Gomes VB, Gueiros LA, Porter SR, Leao JC. Salivary shedding of EpsteinBarr virus and cytomegalovirus in people infected or not by human immunodeficiency virus 1. Clinical oral investigations. 2012; 16(2):659-64.

20. Jenson HB. Epstein-Barr virus. Pediatrics in ReviewElk Grove. 2011; 32(9):375.

21. Levinson W. Review of medical microbiology and immunology: The McGraw-Hill Companies; 2008.

22. Polz-Gruszka D, Morshed K, Stec A, Polz-Dacewicz M. Prevalence of Human papillomavirus (HPV) and Epstein-Barr virus (EBV) in oral and oropharyngeal squamous cell carcinoma in south-eastern Poland. Infectious agents and cancer. 2015; 10(1):37.

23. Coghill AE, Hildesheim A. Epstein-Barr virus antibodies and the risk of associated malignancies: review of the literature. American journal of epidemiology. 2014; 180(7):687-95.

24. Cruz I, Van Den Brule AJ, Brink AA, Snijders PJ, Walboomers JM, Van Der Waal I, et al. No direct role for Epstein-Barr virus in oral carcinogenesis: A study at the DNA, RNA and protein levels. International journal of cancer. 2000; 86(3):356-61.

25. Tsuhako K, Nakazato I, Miyagi J, Iwamasa T, Arasaki A, Hiratsuka $H$, et al. Comparative study of oral squamous cell carcinoma in Okinawa, Southern Japan and Sapporo in Hokkaido, Northern Japan; with special reference to human papillomavirus and Epstein-Barr virus infection. Journal of oral pathology \& medicine. 2000; 29(2):70-9. 
26. Yen CY, Lu MC, Tzeng CC, Huang JY, Chang HW, Chen RS, Liu SY, Liu ST, Shieh B, Li C. Detection of EBV infection and gene expression in oral cancer from patients in Taiwan by microarray analysis. Journal of Biomedicine and Biotechnology. 2009 Jan 1;2009.

27. Bagan L, Ocete-Monchon M-D, Leopoldo-Rodado M, Murillo-Cortes J, Díaz-Fernández J-M, Medina-Gonzalez $\mathrm{R}$, et al. Prevalence of salivary Epstein-Barr virus in potentially malignant oral disorders and oral squamous cell carcinoma. Medicina oral, patologia oral y cirugia bucal. 2016; 21(2):e157.

28. Shamaa AA, Zyada MM, Wagner M, Awad SS, Osman MM, Azeem AAA. The significance of Epstein Barr virus (EBV) \& DNA topoisomerase II alpha (DNA-Topo Il alpha) immunoreactivity in normal oral mucosa, oral epithelial dysplasia (OED) and oral squamous cell carcinoma (OSCC). Diagnostic pathology. 2008; $3(1): 45$

29. Jalouli J, Jalouli MM, Sapkota D, Ibrahim SO, Larsson $\mathrm{P}-\mathrm{a}$, Sand L. Human papilloma virus, herpes simplex virus and epstein barr virus in oral squamous cell carcinoma from eight different countries. Anticancer research. 2012; 32(2):571-80.

30. Kis A, Fehér E, Gáll T, Tar I, Boda R, Tóth ED, et al. Epstein-Barr virus prevalence in oral squamous cell cancer and in potentially malignant oral disorders in an eastern Hungarian population. European journal of oral sciences. 2009; 117(5):536-40.

31. Saravani S, Miri-Moghaddam E, Sanadgol N, Kadeh H, Nazeri MR. Human herpesvirus- 6 and Epstein-Barr virus infections at different histopathological grades of oral squamous cell carcinomas. International journal of preventive medicine. 2014 Oct; 5(10):1231.
32. Wahid A, Ahmad S, Sajjad M. Pattern of carcinoma of oral cavity reporting at dental department of Ayub medical college. J Ayub Med Coll Abbottabad. 2005; 17(1):65-6.

33. Zulfiqar A, Nagi A, Nasim N. A clinicopathological study of orofacial squamous cell carcinoma in local population. Biomedica. 2013; 29(3):147-50.

34. Reddy SS, Sharma S, Mysorekar V. Expression of Epstein-Barr virus among oral potentially malignant disorders and oral squamous cell carcinomas in the South Indian tobacco $\square$ chewing population. Journal of Oral Pathology \& Medicine. 2017; 46(6):454-9.

35. Gonzalez-Moles M, Gutierrez J, Rodriguez M, RuizAvila I, Rodriguez-Archilla A. Epstein-Barr virus latent membrane protein-1 (LMP-1) expression in oral squamous cell carcinoma. The Laryngoscope. 2002; $112(3): 482-7$.

36. Cruz I, Van den Brule A, Steenbergen R, Snijders P, Meijer C, Walboomers J, et al. Prevalence of EpsteinBarr virus in oral squamous cell carcinomas, premalignant lesions and normal mucosa-a study using the polymerase chain reaction. Oral oncology. 1997; 33(3):182-8.

37. Sand LP, Jalouli J, Larsson P-A, Hirsch J-M. Prevalence of Epstein-Barr virus in oral squamous cell carcinoma, oral lichen planus, and normal oral mucosa. Oral Surgery, Oral Medicine, Oral Pathology, Oral Radiology, and Endodontology. 2002; 93(5):58692.

38. Kikuchi K, Ishige T, Ide F, Ito Y, Saito I, Hoshino M, et al. Overexpression of activation-induced cytidine deaminase in MTX-and age-related EpsteinBarr virus-associated B-cell lymphoproliferative disorders of the head and neck. Journal of oncology. 2015; 2015.

\begin{tabular}{|c|c|c|c|}
\hline \multicolumn{4}{|c|}{ AUTHORSHIP AND CONTRIBUTION DECLARATION } \\
\hline No. & Author(s) Full Name & Contribution to the paper & Author(s) Signature \\
\hline 1 & Sana Ghani & $\begin{array}{l}\text { Conception and design } \\
\text { acquisition of data. }\end{array}$ & \\
\hline 2 & Fozia Rauf & Drafting of work. & \\
\hline 3 & Asif Rehman & Critical review of the work. & \\
\hline 4 & Muhammad Irfan & $\begin{array}{l}\text { Analysis and interpretation of } \\
\text { the work. }\end{array}$ & \\
\hline 5 & Fatima lqbal & $\begin{array}{l}\text { Final approval of the version } \\
\text { to be published. }\end{array}$ & \\
\hline 6 & Yousaf Jamal & Final review. & \\
\hline
\end{tabular}

